\title{
Current trends in the entrepreneurial sector in emerging territorial systems
}

\author{
Merciu Florentina-Cristina \\ Cercleux Andreea-Loreta \\ Muşat Ancuța \\ Interdiscipinary Centre for Advanced Researches on Territorial Dynamics, \\ University of Bucharest \\ Faculty of Geography, University of Bucharest Romania \\ krysten1009@yahoo.com,loretacepoiu@yahoo.com,anca_rapid@yahoo.com
}

\begin{abstract}
The purpose of the present paper is an analysis of the complex economic processes within emerging territorial systems. In a short time span, economic enterprises concentrated inside these urban clusters registered a spectacular evolution compared to the surrounding areas. The intensification of the relations between regional and local development hubs and the space that they polarize led to the individualization of territorial systems apart, with spectacular dynamics of the economic-social processes, which make those systems the most dynamic territorial structures. The study sets out to identify the causes determining these complex processes inside the emerging territorial systems, the manner of functional structuring of the space, as well as the causes that determine the evolution of the economic processes inside emerging systems. Research was conducted upon a relevant emerging territorial system, at the level of NACE (Classification of Activities in the National Economy) codes. For each NACE code, an analysis was conducted of the following indicators: the number of companies, the number of employees, turnover and profit.
\end{abstract}

Keywords: entrepreneurial profile, emerging territorial systems, relocation, innovation, territorial management

JEL classification: L 26, P25, R11.

\section{INTRODUCTION}

The concept of entrepreneurship stirs the interest of various categories of actors, large goods-producing companies and high-education institutions standing out among them. The notion of entrepreneurship was given a multitude of interpretations. According to the definition submitted by Shane et Venkataraman (2000) entrepreneurship means a process by whose means are discovered, evaluated and exploited opportunities in creating future products and services. The opportunities are expanded to encompass situations where the new products, services, raw materials and methods of organization are introduced and sold at a price 
higher than their production costs (Casson, 1982). The opportunity is basically a new profitable piece of information a new person has access to, under two conditions: first, if he owns prior knowledge that is complementary to that piece of information and that allows its disclosure, and second, he owns certain cognitive skills enabling evaluation. Possession of that piece of information triggers an entrepreneurial conjucture or vision, a project to capitalize on that opportunity. Other authors refer to organizational emergence, that is, the process that leads to the emergence of a new organization. This view was launched by Gartner (1993) and later enlarged and revisited by other authors, including Aldrich (1999) and Thornton (1999). According to this view, entrepreneurship is expanded to a process grounded into the activities by whose means the opportunity creator mobilizes and combines the resources (informational, material, human etc.) in order to materialize the opportunity into a project.

The studies on polycentric development in Romania highlighted the dynamics of the economic phenomena at the level of territorial systems in the vicinity of national and regional development hubs.

The progress made in the economic sector in post-2000 Romania exerted a positive influence on the development of the entrepreneurial sector and generated a series of changes in the economy of territorial systems. Simultaneously, there occurred the process of delocalization of economic enterprises from inside the polarizing cities, or new economic enterprises arose that featured numerous competitive advantages (lower production costs, multiplication of jobs in the areas close to the cities). This trend is linked to the economic growth in the area polarized by a particular city, as it determines favorable conditions for the economic and human development (Herman, 2011).

Decentralization is one of the guidelines underlying the regional development policy. Industrial decentralization is grounded into a policy of continuous evolution of the production activity, either by way of processes of complete or partial expansion of the functions, or by way of delocalization of certain industrial production facilities (Cepoiu, 2009, p. 152). Decentralisation and industrial relocation are the most active processes in the economic evolution of industrial cities in Romania.

Industrial delocalization is an unavoidable consequence of the global reorganization of the industry, involving, first of all, spatial planning (Cepoiu, 2009, p. 155). The delocalization of an industrial facility is brought about by a pressure towards relocation, for instance a move away from inside the city, where the space is not sufficient or it has become too expensive, environmental-protection expenses included. Delocalization means only a change in location at micro-level and not macro-level, so that the old location factors are not modified (workforce, institutional infrastructure, favorable position from the point of view of the transport routes). Actually, at the moment when the choice for an industrial delocalization/relocation is made, there is a multitude of general factors behind the decision, factors related to production-linked costs and business sector warranties. The costs associated with an operation of this type reside in costs pertaining to related to the workforce, tracts of land, but also related to the taxes levied at the respective destination area (Cepoiu, 2009, p. 155).

Delocalization of economic enterprises out to surrounding settlements is strongly influenced by infrastructure, in general, and by transport infrastructure in particular (Cepoiu, 2009, Peptenatu et al., 2009; Humeau et al. 2010), as the implementation of infrastructure projects is immediately a functional reorganization of the surrounding space. It is important to mention that in Romania the delocalization of economic ventures to the outskirts started after 2000 because of the absence of infrastructure of any kind. After 2000, the apparition of the access routes between the main cities led to the first transfers of economic ventures from within the cities to the outskirts. Once the competitive advantages became apparent, there followed important instances of delocalization of economic ventures onto the routes leading to the nearby cities or along ring roads, built in order to take over transit traffic. A large part of the road infrastructure works were 
conducted by means of European funding. It is a very generally accepted view that financial support received from the European Union generates a large growth surplus (Trón, 2009).

In general emerging behavior arises when a number of entities act within an environment, creating more complex behaviours as a whole (Richard, 2004).

In numerous academic works, the entrepreneurial sector is considered as a source of economic development for a given geographical space (Marshall, 1890; Schumpeter, 1911; Guiso and Schivardi, 2011), the transfer of innovation being an important advantage for the territorial system.

In numerous specialized studies the entrepreneurial behavior is considered as the result of the combined action of three factors (Djankov et al. 2005): perceptions of the local institutional sector, the social networking effects and the individual characteristics (Ardagna and Lusardi, 2010). Additional elements are the perception of the risk, and culture, which are mentioned in numerous works as determining in making the decision to become an entrepreneur (Chiappori and Paiella, 2011; Guiso and Paiella, 2008; Tabellini, 2010; Krueger and Brazeal, 1994; Koellinger et al., 2007; Lüthje and Franke, 2003; Segal et al., 2005).

The importance of studying the economic processes within emerging territorial systems is defended by the need to identify those territorial management systems capable of bestowing the optimal functionality upon the processes shaped up in the wake of the natural interactions between the city and the surrounding space (Peptenatu et al., 2012).

Functional reorganization in areas of urban influence is accompanied by pressure on the components of the natural environment, that is why environment-management models are needed, matching the intensity of the "aggression" (Uygan and Cetin, 2012; Peptenatu et al., 2010a; Braghină et al., 2010, Peptenatu et al., 2011, Braghină et al., 2011; Gümrükçüoğlu, 2011; Ilieş et al., 2012).

Studies concerning the polycentric development of the territorial systems emphasize the trend towards a concentration of the companies in certain polarizing centers inside emerging systems. The polycentric development sets out from the view that an urban system may stand out inside a system of settlements by means of its capability to function as a hub in the redistribution of information (past a certain level of transformation) indispensable to the development of the polarized local systems (Ianoş et al., 2010). The development of entrepreneurial clusters inside emerging structures contributes decisively to the development of the polarization capacity of the entire emerging system. The idea of the importance of a development hub inside a geographical space is mentioned in numerous studies on centrality (Rochefort, 1960; Ianoş et. al., 2010).

\section{MATERIAL AND METHODS}

Emerging territorial systems are spaces close to cities with a great functional complexity, characterized by a spectacular evolution of economic processes. At the level of these territorial structures there are complex interrelations with the polarizing hub.

Defining the limits of the emerging system was conducted by means of the index of functional complexity, calculated as follows:

$$
\mathrm{Cf}=\mathrm{Nd} \frac{N f}{N s}
$$

Cf - functional complexity

$\mathrm{Nd}$ - number of fields according to NACE (Classification of Activities in the National Economy)

$\mathrm{Nf}$ - number of companies (Euro)

Ns - Number of employees 
The dynamics of the entrepreneurial profile was analyzed using statistical data at settlement and NACE code level spanning the years 2001-2010. Several economic indicators were analyzed: the evolution of the number of employees, the evolution of the number of companies, the evolution of profit, the evolution of the turnover. For more relevant analyses, cross-sections of the three main sectors of the economy were carried out: the primary sector (agriculture, extractive enterprises), the secondary sector (processing industry) and the tertiary sector (services).

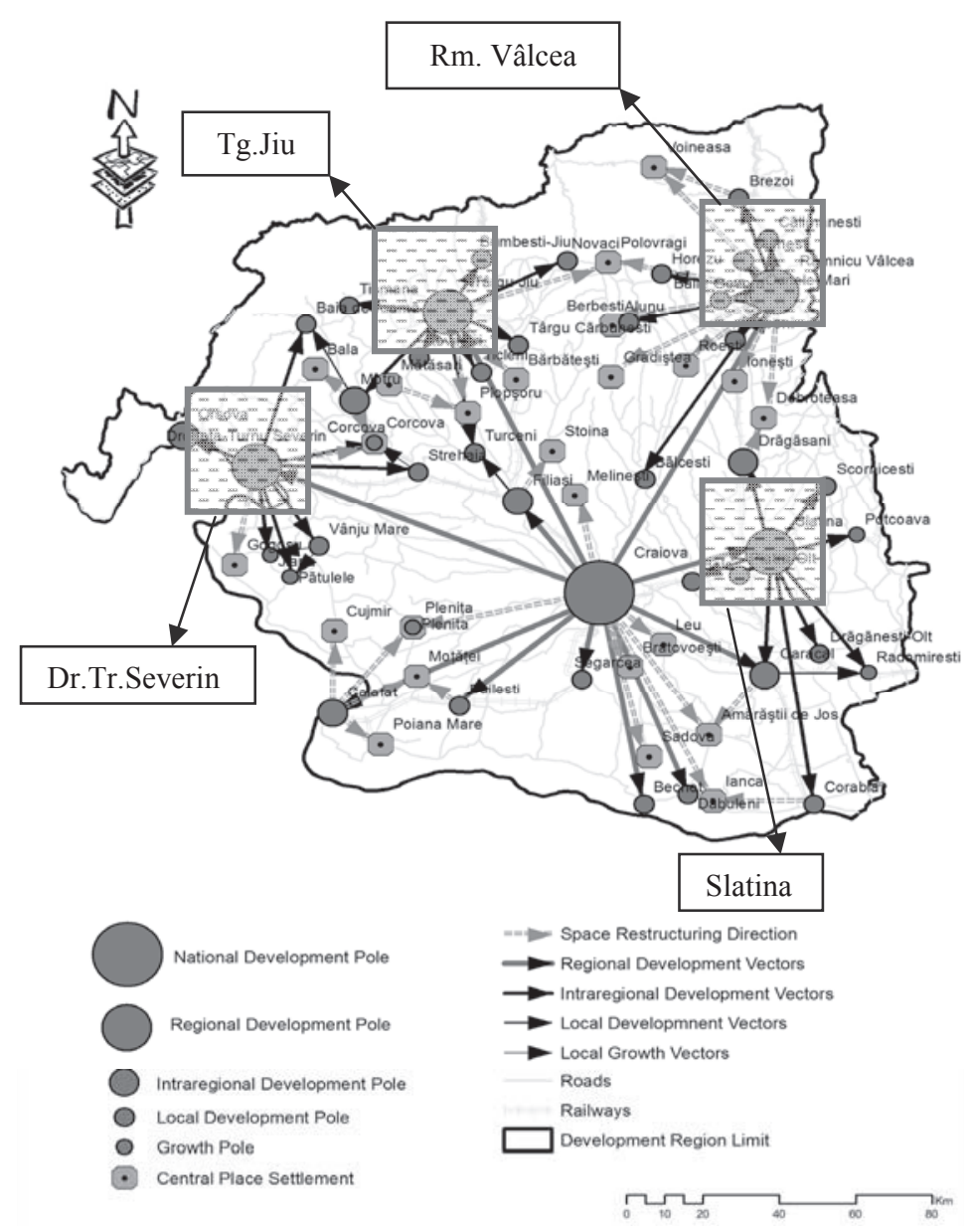

Figure 1. The South-West polycentric network

Source: Peptenatu et al., 2010b

The study traced the way the space between the development hubs is organized along the access routes, by means of the positioning of certain enterprises in those areas. Depending on the manner and the complexity of the organization, we advanced two concepts, that of organizing axis (an axis able, by means of the benefits offered, to win over investments, which would enable a functional rejuvenation of the territory 
along the access routes between the development hubs) and the concept of development corridor (an axis with a higher level of organization) (Peptenatu et al., 2009). The starting point was the strategy for polycentric development created by the Interdisciplinary Center for Advanced Research into Territorial Dynamics (Peptenatu et al., 2009), where a polycentric network was designed, which comprises the development hubs and the main directions of interaction between them. In addition, the development corridors and organizing axes shaped up in the wake of interaction between the development cores were also drafted.

The development hubs were arranged into a hierarchy depending on the polarization capacity, calculated by means of five criteria: size and demographic attractiveness, economic power and competitiveness, polarization capability by means of services in the higher tertiary sector, the number of lower-rank towns inside the area of influence, territorial representativeness and the outlooks of supporting the consolidation of the regional settlement system. Aggregating these indicators resulted in an index of the polarization capacity of the two cities. Field research and a thorough research of statistical data identified the main directions of interaction, as well as the relations established at the level of the local networks, for each development hub (Fig.1), an important step towards defining the regional context of the processes inside the areas of urban influence.

After defining the regional polycentric network, the areas of urban influence were next identified, by means of the following criteria: the convergence of the transport systems, economic development, demographic characteristics and the socio-cultural criterion.

The research on the creation of emerging systems unfolded in the Oltenia South-Western Development Region, one of the eight development regions in Romania. The dynamics of the entrepreneurial sector were analyzed in two emerging systems centering on the cities of Targu Jiu and Drobeta Turnu Severin, territorial systems with more than 126,000 inhabitants and more than 130,000 inhabitants, respectively.

Figure 2. The Drobeta Turnu Severin influence area

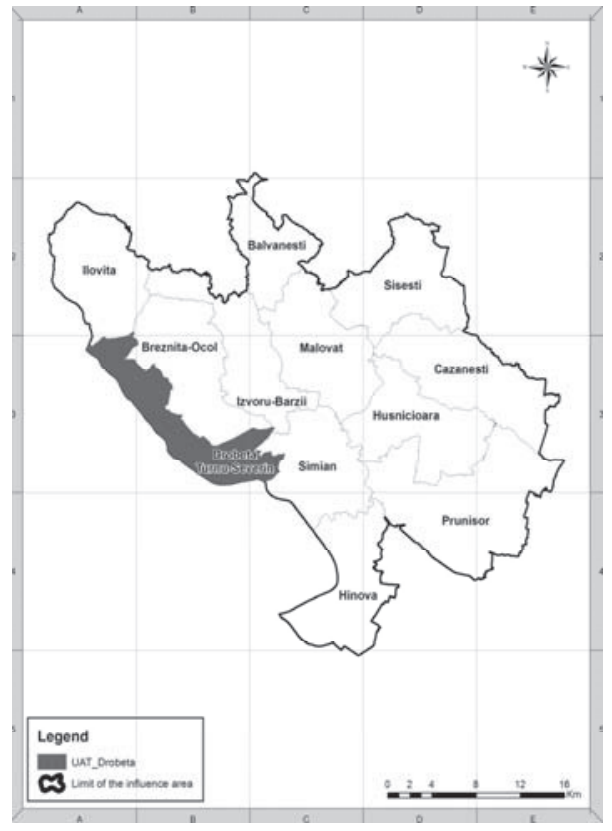

Figure 3. The Targu Jiu influence area

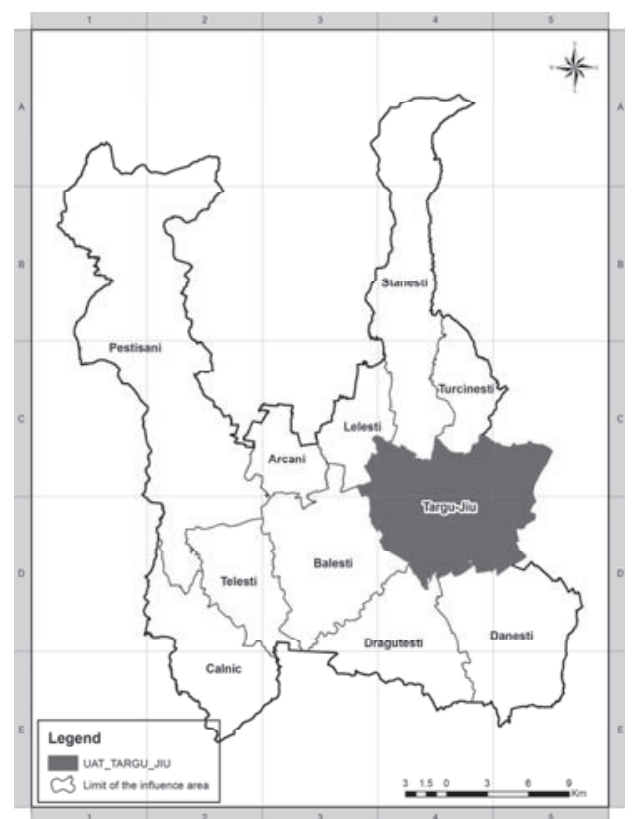




\section{RESULTS}

The in-depth analyses carried out at the level of the two emerging territorial systems highlighted important differences across the board as far as all indicators analyzed are concerned. Choosing the two case studies was not random, as the goal was to highlight the evolution of the entrepreneurial sector at the level of the intraregional development centers under study. The selection of the two case studies was determined, on the one hand, by a desire to highlight the relations that are established between polarizing cities and their areas of influence at the level of the size category of the two municipalities under the conditions of the presence and escalation of the economic crunch. On the other hand there were taken into consideration the shared characteristics of the two municipalities (demographic size, the economic nature of their areas of influence) and the manner of economic and social evolution in the context of the differences that arise as a result of their location inside the South-Western development region (Drobeta Turnu Severin has a peripherial position, unlike the city of Targu Jiu which has a relatively central position). The particularity of the geographical conditions strongly influences the economic and social profile of the area of influence of a particular city (for instance the location of the city of Targu Jiu in a hill region had a strong influence on the economy of the area it polarizes, with agriculture being the predominant activity, alongside mining in certain areas, as a result of the presence of the underground resources; nowadays there emerges a trend towards the development of rural tourism and agri-tourism in the upper piedmont region which borders the city of Targu Jiu, especially to its North, coinciding with the Northern part of the ancient province of Oltenia).

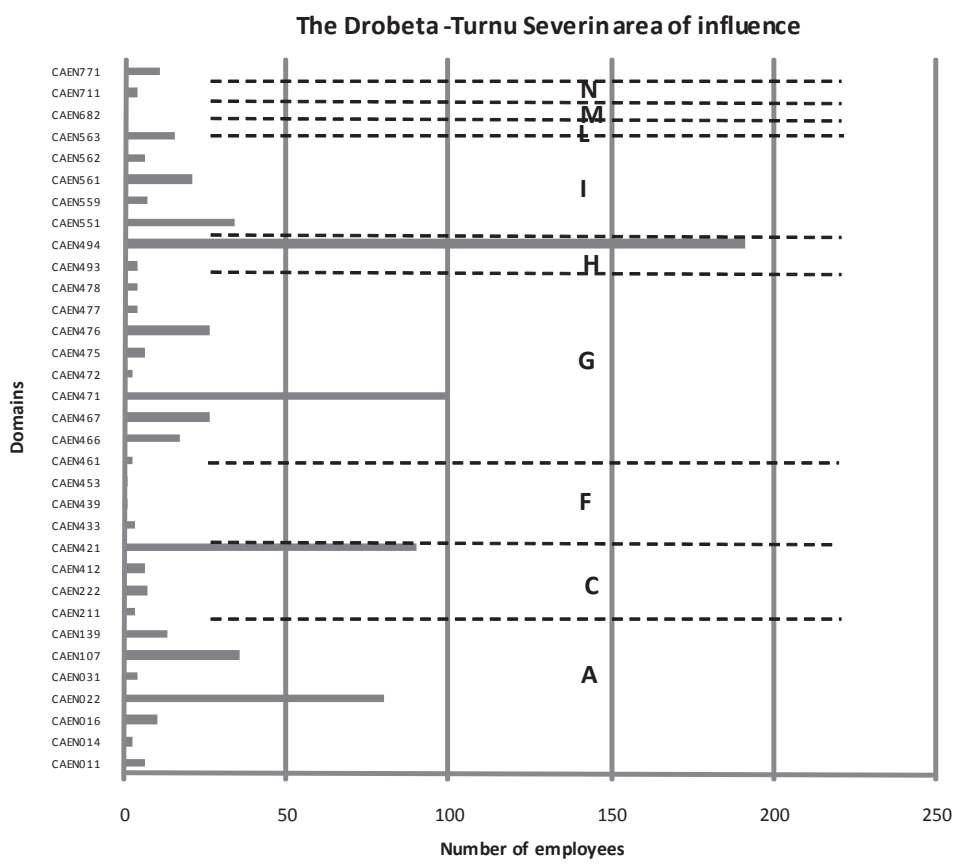

Figure 4. The weight of the number of employees per fields of trade present within the area of influence of the city of Drobeta Turnu Severin 
The area of influence of the city of Drobeta Turnu Severin is characterized by a limited functional complexity, related to the economic decline of the polarizing center. By 2010 there were a total of 33 fields of trade present inside the Drobeta Turnu Severin emerging area, four of them (retail in unspecialized stores, construction work and logging) with more than 50 employees each, and only one field of trade with more than 150 employees (commodity transport by road) (fig. 4).

A. Agriculture, forestry and fishery; C. Processing industry; F. Constructions; G. Wholesale and retail trade, motovehicle and motorcycle repair; H. Transport and storage; I. Hotels and restaurants; M. Professional, scientific and technical activities; N. Activities of administrative services and activities of support services

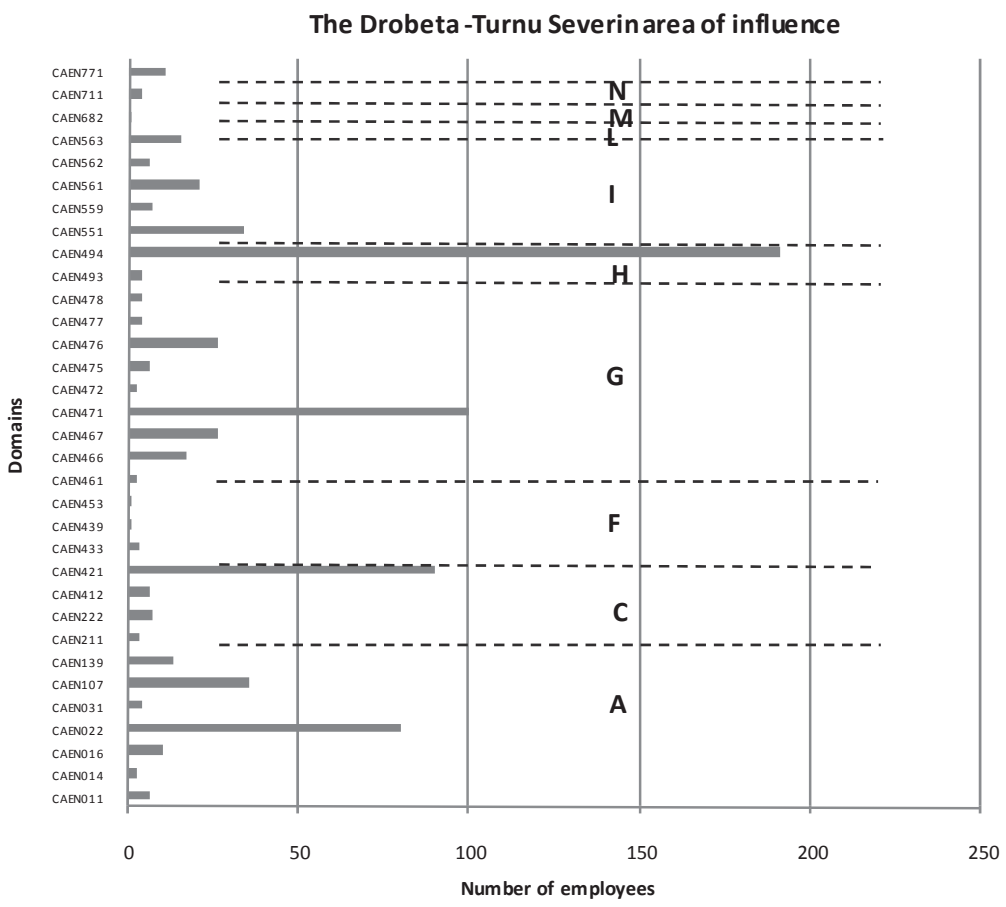

Figure 5. The characteristics of the entrepreneurial sector within the Drobeta Turnu Severin emerging system (2010): a) number of firms b) turnover

The infrastructure had an strong influence on the economy of the Drobeta Turnu Severin emerging system, as well as the evolution of the main economic indicators. The peripherial position of the polarizing center inside the national network of settlements and the undersized road infrastructure led to the economic decline of the polarizing center, and implicitly to a weak functional organization in its surrounding space.

The implementation of infrastructure projects during 2011 created the foundations for the development of the entrepreneurial sector inside the urban-rural interface of the city of Drobeta Turnu Severin, where the inauguration of a ring road was followed by several investment projects along that road, with major space-consuming economic enterprises meant to serve the polarizing center. 
The process of functional organization within the area of influence of the city of Targu Jiu is in an incipient phase, but there can be noticed an important evolution of the economic enterprises, because the number of economic ventures increase by $36 \%$ during 2007-2010, reaching 38 .

The Targu Jiu area of influence

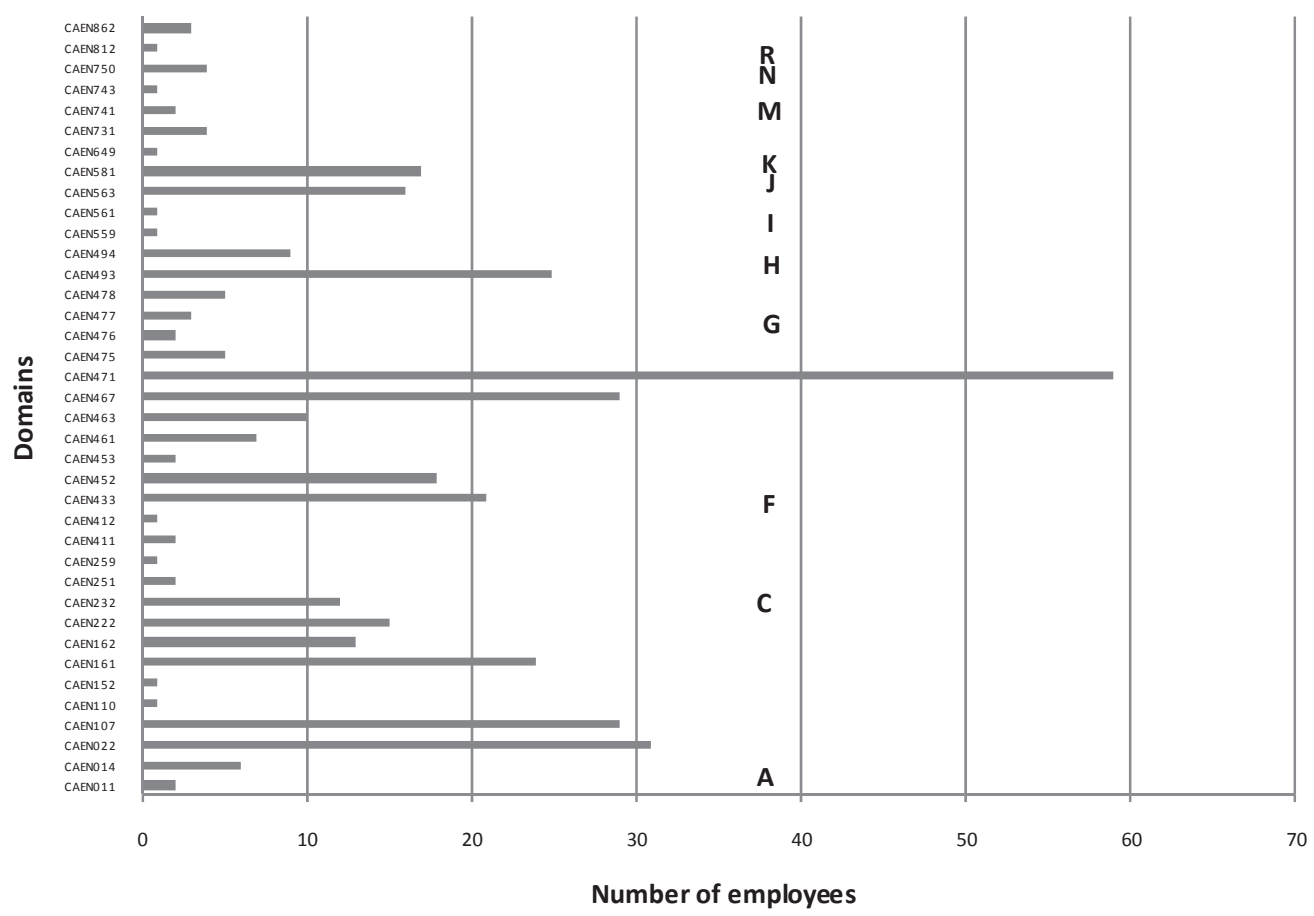

Figure 6. The weight of the number of employees per fields of trade present within the area of influence of the city of Targu Jiu

A. Agriculture, forestry and fishery; C. Processing industry; F. Constructions; G. Wholesale and retail trade, motorvehicle and motorcycle repair; H. Transport and storage; I. Hotels and restaurants; J. Activities of publishing books, newspapapers, magazines and other publishing activities; K. Financial intermediation activities exclusively insurance and pension funds; M. Professional, scientific and technical activities; N. Activities of administrative services and activities of support services; R. Ambulatory healthcare activities

The number of employees exceeds 50 only in the field of retail in unspecialized stores Constructions, timber processing, bakery production, motorvehicle repair, specialized retail, transport and publishing enterprises are the economic fields that registered a significant evolution(fig. 6).

The outlooks for the development of this emerging structure are linked to the development of road infrastructure that would connect the polarizing city and Pan-European Corridor IV and to the development of road infrastructure leading to the tourist destinations in Northern Oltenia. 
The Targu Jiu area of influence

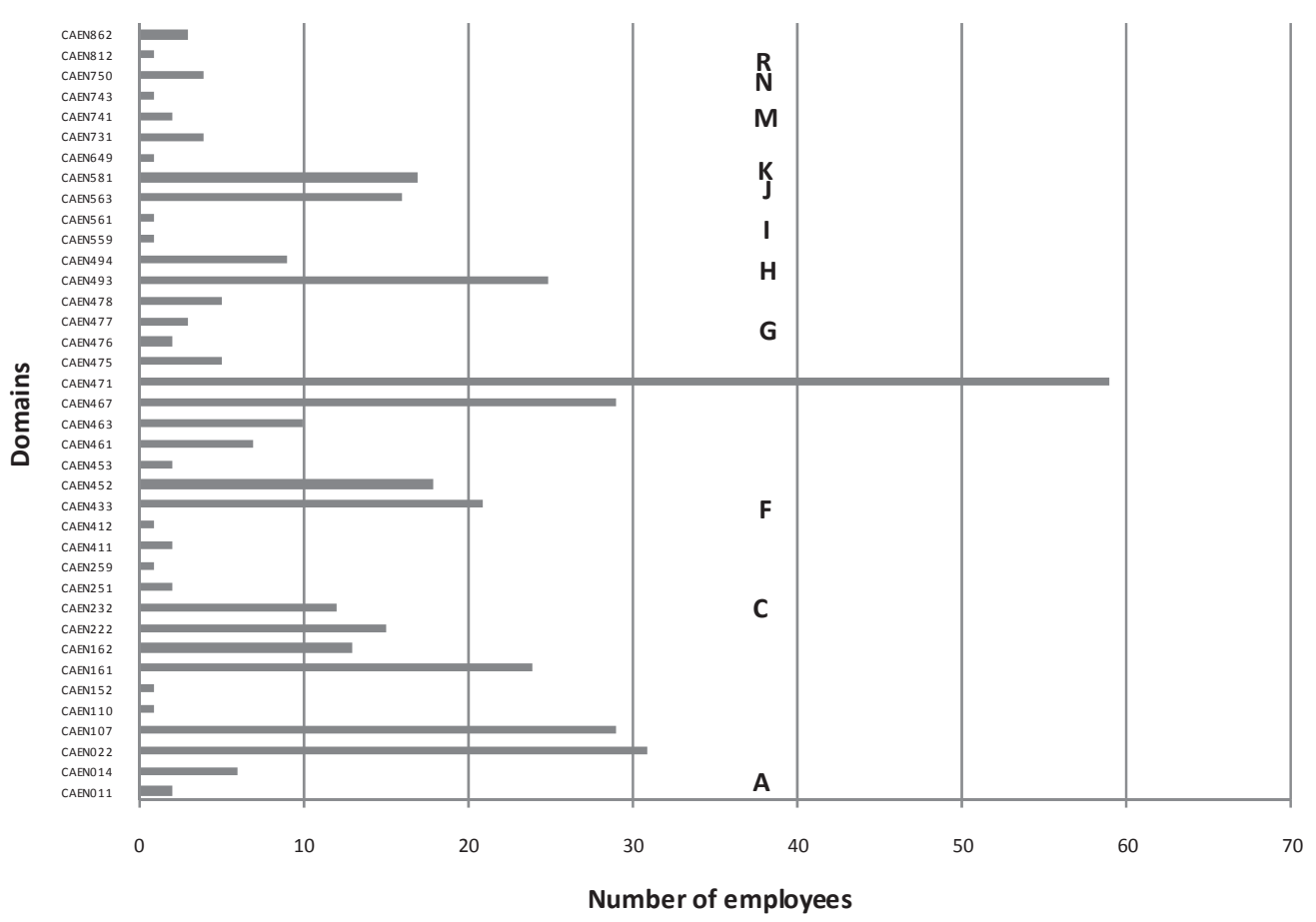

Figure 7 . The characteristics of the entrepreneurial sector within the Targu Jiu emerging system (2010): a) number of firms b) turnover

The evolution of the structure of the main economic sectors emphasizes the upward trend of the turnover in the tertiary sector and the primary sector, as well as the decline in importance of the revenue registered by the secondary sector. The link between the evolution of the turnover and profit indicates important differences as far as the profit reinvested in development is concerned at the level of the three economic sectors.

The ratio between the weight of companies and of the employees, at the level of the main sectors of the economy, reveals the general trends of evolution at the level of the emerging territorial system. Even if there is no direct link between the weight of companies and the weight of the employees, there may be noticed a trend towards the tertiarization at the level of the entire emerging territorial system and the decline in the importance of the secondary sector. The primary sector registers a slight upward trend because of agricultural auxiliary activities.

\section{DISCUSSION}

The results of this study reveal the differentiated effects across the territory of the national policies dealing with the development of the entrepreneurial sector. The emerging territorial systems are vital areas around the big crowded cities and the destination of economic ventures delocalized in a search for competitive advantages. 
Studying the complex processes inside the emerging territorial systems is of outstanding importance, as in-depth analyses underlie the territorial management systems capable of bestowing the optimal territorial functioning to the processes shaped up in the wake of natural interactions between the city and the surrounding space. The need for territorial development strategies arises in numerous studies that insist on identifying the need for orientation of certain natural evolutions, so as to achieve the optimal functioning across a particular territory (Abler, 1970, Bassand, 2004; Rhodes, 1997; Bourdeau-Lepage and Huriot, 2003).

Several differences, too, can be noticed at the level of the two case studies. Inside the Targu Jiu emerging territorial system, there can be sensed the influence of the policies enforced at county level, consisting in the need to continue mining operations in Gorj county. This action is due to the presence of the underground resources used in energy generation at the Rovinari and Turceni thermo power plants. Preserving the mining sector that supplies raw materials to the thermo power plants in the county (inside the area of influence of the city of Targu Jiu there is one of the biggest lignite mines in Gorj county, in the commune of Calnic: the Tismana I and II pits) was planned as an alternative in lowering Romania’s dependence on Russian gas. Because of the rich mineral resources used in energy generation found in Romania, the degree of dependence on imported gas is lower compared to other European countries'. Nevertheless, authorities consider the possibility of lowering dependence on imported energy sources even more by increasing the output of efficient coal mines. To that goal, a new energy strategy has been designed, which will involve the use of the mining system to a much higher degree in the production of electricity.

Unlike the city of Targu Jiu, the city of Drobeta Turnu Severin registered a decline of the industrial sector, both in the branches of heavy industry and in the light industry (the shipyards, the railcar factory, the cellulose and paper mill, the timber processing plant, the brewery).

The importance of conducting extractive operations in Gorj county also exerted a positive influence on preserving the role of polarizing city of the city of Targu Jiu, for the reason that it hosts the headquarters of the lignite-mining company, which enjoys the constant support of the state, under the form of financial subsidies. The mining sector is one of the few sectors of the national economy that, despite the significant decline in production and the number of employees, endures at the level of the local and regional economies, unlike other branches of the industry where production facilities went bankrupt and were either shut down or privatized. Even in those situations where the industrial facilities were privatized, many of them no longer registered any positive economic evolution.

An aspect shared by the two emerging systems is that in the past few years there has been a noticeable diversification of the entrepreneurial profile both inside the polarizing cities and inside their area of influence, noticing an increase in the number of economic ventures that do business in trade and services, alongside the decline of industrial production and the number of employees. The evolution of the economic sector in both municipalities was influenced by the dynamics of the creation of commercial enterprise.

The concentration of the population and of the economic ventures over a short period of time determines dysfunctionalities in the relation between those components and the natural environment. The permanent functional reorganization and the ever-rising concentration of economic ventures inside emerging territorial systems have brought about the need for the creation of territorial management models, that would optimize the complex interactions among the components of the emerging territorial system (Uygan and Cetin, 2012; Peptenatu et al., 2010; 2011; 2012; Braghină et al., 2010, Peptenatu et al., 2011, Braghină et al., 2011; Gümrükçüoğlu, 2011). 


\section{CONCLUSIONS}

The development of the entrepreneurial sector is strongly influenced by the socio-economic backdrop where the decision to develop a business is made, as a view across the territory reveals the obvious differences between urban, rural, urban influence areas and severely underprivileged areas.

The emerging territorial system is a discontinuous area of interactions, with a great structuring capability, born as a result of the economic evolution of the polarizing core, which has a fundamental contribution to the dynamics of the economy of the crowded urban spaces.

The conclusions of this study confirm to a certain degree the theory of the emerging evolution, which asserts that the emergence of the new qualities is absolutely spontaneous and unpredictable, in the sense that the emerging territorial system is a new quality, distinct by means of the dynamics and characteristics of the economic processes. However there can be no claim of spontaneous and unpredictable apparition because these spatial structures are the direct result of the interaction between a city with a polarizing capacity and a space that can offer numerous competitive advantages. Moreover, the evolution of the emerging territorial systems may be influenced by decision-making impulses by the decision-makers.

The research conducted at the level of the selected case studies reveals that although they are two cities with similar polarization capabilities, the differences concerning the type of relations that are established between the cities and the space within their polarization area, as well as the physical and geographical conditions may bring about differences in their economic profile. Just as important are the effects of the policies enforced at regional level, which can influence both the economy of the urban areas and that of rural areas.

\section{ACKNOWLEDGEMENTS}

This work was supported by the project Territorial Management Based on Growth Poles Theory (UEFICSU-PNII - Idei, 1950) and the strategic grants POSDRU /89/1.5/S/58852: "Program for postdoctoral researchers in science education" and POSDRU /88/1.5/61150 "Doctoral studies in the field of Life and Earth Sciences", co-financed by the European Social Fund within the Sectoral Operational Program Human Resources' Development 2007-2013.

\section{REFERENCES}

Abler, R. (1970), What Makes Cities Important, Bell Telephone Magazine.

Ardagna, S., Lusardi, A. (2010), Heterogeneity in the effect of regulation on entrepreneurship and entry size, Journal of the European Economic Association, 8 (2-3), p.594-605.

Audretsch, D.B., Keilbach, M. (2004), Entrepreneurship capital and economic performance, Regional Studies, 38 (8), p.949-959.

Bassand, M. (2004), La métropolisation de la Suisse. Lausanne, Presses Polytechniques et Universitaires Romandes.

Bourdeau-Lepage, L., Huriot, J.-M. (2003), Metropolises and Global Coordination. A Historical perspective, AFSE Congress 2003, Paris.

Braghină, C., Peptenatu, D., Constantinescu, Şt., Pintilii, R.D., Drăghici, C. (2010), The pressure exerted on the natural environment in the open pit exploitation areas in Oltenia, Carpathian Journal of Earth and Environmental Sciences, 5(1), p.33-40. 
Braghină. C., Peptenatu, D., Drăghici, C., Pintilii, R.D., Schvab, A. (2011), Territorial management within the systems affected by mining.Case study the South-Western Development Region in Romania, Iran. J. Environ. Health. Sci. Eng., 8 (4), p. 342-352.

Brenner, N. (2003), Metropolitan Institutional Reform and the Rescaling of State Space in Contemporary Western Europe, European Urban and Regional Studies, 10(4), p. 297-324.

Brenner, N. (2004), Urban governance and the production of new state spaces in Western Europe, 1960-2000, Review of International Political Economy, 11, p.447-488.

Burinskienė, M.; Rudzkienė, V. (2009), Future insights, scenarios and expert method application in sustainable territorial planning, Technological and Economic Development of Economy, 15(1), p. 10-25.

Casson, M. (1982), The entrepreneur, Towata, NJ: Barnes \& Noble Books (translated by Pierre Jeanblanc, L'entrepreneur, Economica, 1991).

Cepoiu, A. L., (2009), The role of industrial activities in developing the settlements in the Metropolitan Area of Bucharest, Bucharest: Universitara Press [in Romanian, conclusions in English].

Chiappori, P.-A., Paiella, M. (2011), Relative risk aversion is constant: evidence from panel data, Journal of the European Economic Association, 9, p. 1021-1052.

Djankov, S., Miguel, E., Qian, Y., Roland, G. and Zhuravskaya, E. (2005), Who are Russia’s entrepreneurs?, Journal of the European Economic Association, 3, p.587-597.

Fischer, E.M., Reuber, A.R., Dyke, L.S. (1993), A theoretical overview and extension of research on sex, gender and entrepreneurship, Journal of Business Venturing, 8 (2), p.151-168.

Gartner, W.B. (1993), What are we talking about when we talk about entrepreneurship?, Journal of Business Venturing, 5(1), p. 15-28.

Guiso, L. and Paiella, M. (2008), Risk aversion, wealth, and background risk, Journal of the European Economic Association, 6, p. 1109-1150.

Guiso, L. and Schivardi, F. (2011) What determines entrepreneurial clusters?, Journal of the European Economic Association, 9, p. 61-86.

Gümrükçüoğlu, M. (2011), Urban air pollution monitoring by using geographic information systems: a case study from Sakarya, Turkey, Carpathian Journal of Earth and Environmental Sciences, 6( 2), p. 73-84.

Herman, E. (2011), The Impact of Economic Growth Process on Employment in European Union Countries, The Romanian Economic Journal, 42, p. 47-67.

Humeau, J. B., Peptenatu, D., Pintilii, R., Drăghici, C., Schvab, A. (2010), The Role of Polycentric Network in the Demographic Dynamic of Human Settlements, J. of Urban and Regional Analysis, 2 (1), p. 25-37.

Ianoş, I., Humeau, J.-B., Tălângă, C., Braghină, C., Ancuța, C., Bogdan L. (2010), Ethics of Space and the Treatment of Most Disadvantaged Areas, Carpathian Journal of Earth and Environmental Sciences, 5(2), p. 211-217.

Ilieş, A., Dehoorne, O., Ilieş D.C. (2012), The cross-border territorial system in Romanian Ukrainian Carpathian area. Elements, mechanisms and structures generating premises for an integrated crossborder territorial system with tourist function, Carpathian Journal of Earth and Environmental Sciences, 7 (1), p. 27-38.

Koellinger, P., Minniti, M., Schade, C. (2007), I think I can, I think I can: Overconfidence and entrepreneurial behavior, Journal of Economic Psychology, 28 (4), p. 502-527.

Krueger, N., Brazeal, D.V. (1994), Entrepreneurial potential and potential entrepreneurs, Entrepreneurship Theory and Practice, 18 (3), p. 91-104.

Loo, B. P. Y.; Chow, S. Y. (2006), Sustainable urban transportation: concepts, policies, and methodologies, Journal of Urban Planning and Development-ASCE, 132(2), p. 76-79.

Lüthje, C., Franke, N. (2003), The 'making' of an entrepreneur: testing a model of entrepreneurial intent among engineering students at MIT., R\&D Management, 33 (2), p. 135-147. 
Marshall, A. (1890), Principles of Economics. London: Macmillan.

Muşat A. (2012), Territorial management in disadvantaged areas of South West development management, PhD thesis, manuscript, Bucharest: University of Bucharest.

Peptenatu, D., Pintilii, R.D., Cepoiu L., Drăghici C., (2009), Polycentric development strategy - an efficient instrument in administrative decentralization, Romanian Review on Political Geography, 2(2), p. 99-111.

Peptenatu, D., Pintilii, R.D., Draghici, C., Stoian, D. (2010a), Environmental pollution in functionally restructured urban areas: case study - the city of Bucharest, Iran. J. Environ, Health. Sci. Eng., 7(1), p. 87-96.

Peptenatu, D., Pintilii R., Peptenatu, A., Draghici, C. (2010 b), The role of rural settlements occupying a central position in the elaboration of the strategies of territorial management. Case study the Southwestern Development Region, Romanian Review on Political Geography, 2, p. 411-427.

Peptenatu, D., Pintilii, R.D., Draghici, C. (2011), Environmental risk management of urban growth poles regarding national importance. Int. J. Environ. Sci. Tech., 8(4), p. 737-746.

Peptenatu, D., Merciu, C., Merciu, G., Drăghici, C., Cercleux. A.L. (2012), Specific Features of Environment Risk Management in Emerging Territorial Structures, Carpathian Journal of Earth and Environmental Sciences, 7(2), p. $135-143$.

Reynolds, P.D. (1997), Who starts new firms? - Preliminary explorations of firms-in-gestation, SmallBusiness Economics, 9 (5), p. 449-462.

Rhodes, R.A.W. (1997), Understanding Governance. Policy Networks, Governance, Reflexivity and Accountability, Open University Press, Buckingham.

Richard, J. A. (2004), Natural Inspiration for Self-Adaptive Systems, Database and Expert Systems Applications, 15th International Workshop on (DEXA'04), p. 732-736.

Schumpeter, J. (1911), The Theory of Economic Development, New Jersey: Harvard University Press.

Segal, G., Borgia, D., Schoenfeld, J. (2005), The motivation to become an entrepreneur, International Journal of Entrepreneurial Behavior \& Research, 11 (1), p. $42-56$.

Shane, S., Venkataraman S. (2000), The Promise of entrepreneurship as a field of research, Academy of Management Review, 25 (1), p. 217-226.

Tabellini, G. (2010), Culture and Institutions: Economic Development in the Regions of Europe, Journal of the European Economic Association, 8, p. 677-716.

Thornton, P.H. (1999), The sociology of entrepreneurship, Annu. Rev. Sociol., 25, p. $19-46$.

Trón, Z. (2009), Evaluation Methods of European Regional Policy and Reasons for Different Outcomes, The Romanian Economic Journal, 32 (2), p.149-185.

Uygan, D., Cetin O. (2012), Mapping boron pollution using GIS for boron-affected soils in Western Turkey, Carpathian Journal of Earth and Environmental Sciences, 7 (1), p. 89-94. 